\title{
Null mutation of the prolactin receptor gene produces multiple reproductive defects in the mouse
}

\author{
Christopher J. Ormandy, ${ }^{1}$ Anne Camus, ${ }^{2}$ Jacqueline Barra, ${ }^{2}$ Diane Damotte, ${ }^{3}$ Brian Lucas, ${ }^{1}$ Hélène \\ Buteau, ${ }^{1}$ Marc Edery, ${ }^{1}$ Nicole Brousse, ${ }^{3}$ Charles Babinet, ${ }^{2}$ Nadine Binart, ${ }^{1,4}$ and Paul A. Kelly ${ }^{1}$ \\ ${ }^{1}$ Institut National de la Santé et de la Recherche Médicale (INSERM) Unité 344, Endocrinologie Moléculaire Faculté de \\ Médecine Necker, Paris, France; ${ }^{2}$ Unité de Biologie du Développement Unités de Recherches Associées Centre National de \\ la Recherche Scientifique (CNRS) IP 1960, Institut Pasteur, Paris, France, ${ }^{3}$ Service d'Anatomo-Pathologie, Hôpital \\ Necker-Enfants Malades, Paris, France
}

\begin{abstract}
Mice carrying a germ-line null mutation of the prolactin receptor gene have been produced by gene targeting in embryonic stem cells. Heterozygous females showed almost complete failure of lactation attributable to greatly reduced mammary gland development after their first, but not subsequent, pregnancies. Homozygous females were sterile owing to a complete failure of embryonic implantation. Moreover, they presented multiple reproductive abnormalities, including irregular cycles, reduced fertilization rates, defective preimplantation embryonic development, and lack of pseudopregnancy. Half of the homozygous males were infertile or showed reduced fertility. This work establishes the prolactin receptor as a key regulator of mammalian reproduction, and provides the first total ablation model to further study the role of the prolactin receptor and its ligands.
\end{abstract}

[Key Words: Prolactin receptor gene; mouse reproduction]

Received September 23, 1996; revised version accepted November 22, 1996.

Prolactin is a $23-\mathrm{kD}$ peptide synthesized and secreted by the lactotrophic cells of the anterior pituitary of all vertebrates, and by various extrapituitary sites including decidual cells of the placenta (Lee and Markoff 1986), lymphocytes (Montgomery et al. 1990; Pellegrini et al. 1992), and breast cancer cells of epithelial origin (Clevenger et al. 1995; Ginsberg and Vonderhaar 1995). Prolactin is the major ligand for the prolactin receptor (PRLR), although during pregnancy additional ligands are present in some members of Rodentia and Artiodactyla, where prolactinlike placental lactogens are synthesized and secreted by placental giant trophoblast cells of fetal origin. In primates, pituitary and placental growth hormone, placental growth hormone variants, and the growth hormonelike placental lactogens, all bind to the PRLR. Hormones that bind the PRLR are collectively termed lactogenic hormones (Forsyth 1986, 1991).

The PRLR is a trans-membrane protein belonging to the cytokine receptor superfamily (Bazan 1989), which is expressed as short and long forms, differing in the length and sequence of their cytoplasmic tails (Boutin et al. 1988, 1989; Davis and Linzer 1989), because of alternative splicing of a single PRLR gene (Arden et al. 1990; Shirota et al. 1990). The PRLR is expressed at widely

${ }^{4}$ Corresponding author.

E-MAIL kelly@necker.fr; FAX 33-143060443. varying levels in virtually all tissues, both adult and fetal (Nagano and Kelly 1994; Freemark et al. 1995; Royster et al. 1995). The short and long forms are expressed differentially, or regulated during the estrous cycle and pregnancy (Buck et al. 1992; Clarke et al. 1993; Clarke and Linzer 1993), which suggests that they may initiate distinct signaling pathways. Although both forms of the PRLR are dimerized by the binding of a single molecule of prolactin to activate the JAK2, Fyn, and mitogen-associated protein (MAP) kinase systems, and can stimulate cell growth (Das and Vonderhaar 1995; Lebrun et al. $1995 \mathrm{a}, \mathrm{b}$ ) only the long form of the receptor can activate the Stat5 transcription factor and initiate milk protein gene transcription (Gouilleux et al. 1994).

The best characterized role of lactogenic hormones is the stimulation of mammary gland development during pregnancy and postpartum regulation of lactation (Neville and Daniel 1987). In addition, prolactin may influence the normal activity of similar secretory glands, such as the prostate (Costello and Franklin 1994), and the lacrimal gland (Warren et al. 1994), and provide a proliferative stimulus to tumors of the breast and prostate (Biswas and Vonderhaar 1987; Costello and Franklin 1994). A number of other effects have been attributed to these hormones. Prolactin may regulate gonadal functions, such as steroidogenesis and corpus luteum formation, and modulate the effects of the gonadotropins 
through regulation of luteinizing hormone receptors (Kelly et al. 1991). Nest building and pup retrieval are postulated to be prolactin regulated through PRLRs in the medial preoptic area of the brain (Bridges 1994). Prolactin may also exert multiple effects in the immune system (Gala 1991) and the prolactin-stimulated autoimmune disease systemic lupus erythematosus responds to pituitary prolactin inhibition by bromocriptine /Walker et al. 1995). The adrenal glands express extremely high levels of PRLR, and adrenal secretion of dehydroepiandrosterone (DHEA) and dehydroepiandresterone sulfate (DHEAS) may be prolactin regulated (Parker and Odell 1980; Adams 1985). In the liver, another rich source of PRLR, prolactin increases $\mathrm{Na}^{+}$-dependent transport of taurocholate and an unidentified factor that synergizes with prolactin for the growth of prolactin target tissues (Buckley et al. 1985; Nicoll et al. 1985; Liu et al. 1995). These are just some of the more than 85 effects attributed to prolactin in vertebrates (Nicoll and Bern 1972; Nicoll 1980); however, almost all of these effects are the subject of conflicting observations and despite the accumulation of an enormous body of literature $(>27,000$ papers retrievable from MEDLINE by "prolac$\operatorname{tin}^{\prime \prime}$ ), precise roles of lactogenic hormones, with the exception of direct mammary effects, remain largely unproven. Thus, lactogens remain well-characterized hormones with poorly characterized functions.

One of the major causes of this dilemma is the inherent deficiency of the experimental models used to date. In vivo, two (now classic) animal models are currently used. One uses pituitary ablation, achieved either by hypophysectomy, or administration of dopamine $\mathrm{D}_{2}$ receptor agonists to reduce pituitary prolactin secretion; the second is based on the use of spontaneous mutant dwarf mice strains, lacking pituitary somatotrophs and lactotrophs. These models are, however, severely compromised by incomplete prolactin depletion, and by the unavoidable suppression of other pituitary and nonpituitary hormones. In vitro models suffer similar limitations. Fetal calf serum, an essential component of most cell and tissue culture media, contains high concentrations of lactogenic hormones that are difficult to remove (Biswas and Vonderhaar 1987). In addition, a growing list of cell types synthesize and secrete prolactin (Pellegrini et al. 1992; Ginsberg and Vonderhaar 1995/ making complete prolactin removal impossible. These combined factors have made effects mediated by the PRLR difficult to demonstrate in vitro and in vivo, resulting in the many conflicting and contradictory observations concerning prolactin.

The advent of gene targeting in mice (Thomas and Capecchi 1987) has provided a way to overcome these problems. We have used this approach to remove the PRLR from the set of expressed genes in the mouse, and have produced the first experimental model where the effects of a complete absence of prolactin receptor mediated signaling of lactogenic hormones can be observed. Cell lines derived from this mouse offer the potential of in vitro models to further explore the indirect and direct effects of prolactin.

\section{Results \\ Gene cloning, vector construction, and generation of $P R L R^{-1-}$ mice}

An 129/Sv mouse genomic DNA library constructed using Lambda DASHII (Stratagene) was screened using the mouse PRLRS3 cDNA (Davis and Linzer 1989). The coding region of the PRLR gene was isolated as a series of clones spanning $\sim 80 \mathrm{~kb}$ of DNA. The exon positions were determined by extensive restriction enzyme site mapping and Southern blot analysis. The intron/exon junctions were determined by genomic DNA sequencing (C.J. Ormandy, N. Binart, and P.A. Kelly, in prep.). A portion of the coding region is shown in Figure 1A. Exons 4 and 5 were each found to contain a pair of extracellular cysteine residues. Loss of just one of these cysteines results in complete lack of hormone-binding activity (Rozakis-Adcock and Kelly 1991). A targeting construct was prepared with $7.5 \mathrm{~kb}$ of overall homology in which a 1.5 -kb fragment containing exon 5 was replaced with the similarly sized thymidine kinase-neomycin resistance gene ( $T k-n e o)$ cassette, which resulted in a mutation creating an in-frame stop codon. Thus, if a mRNA was transcribed from this mutated gene, it would encode a very short protein of 44 amino acids, without any of the functional domains required for ligand binding, membrane insertion, or signal transduction. After electroporation into E-14.1 embryonic stem cells and neomycin selection, 3 of 214 G418-resistant clones were found to have undergone $3^{\prime}$ and $5^{\prime}$ homologous recombination using Southern blot analysis with the appropriate restriction enzymes and probes (see Fig. $1 \mathrm{C}$ for the 3 ' homologous recombination, data not shown; see also Materials and Methods). Two of these clones, E8 and $\mathrm{H} 2$, were used for microinjection into 3.5 -day-old C57BL/6 blastocysts and were able to generate germ-line chimeras. The presence of the mutated allele in the $F_{1}$ progeny of the chimeras was revealed by Southern analysis (Fig. 1D). $F_{1}$ intercrosses revealed a genotype distribution not significantly different from the normal Mendelian ratios $(26 \%+/+$, $47 \%+/-, 27 \%-/-$ ) excluding the first generation / see below).

\section{PRLR gene expression in PRLR ${ }^{-1-}$ mice}

The expression of the mutated PRLR gene was examined using RT-PCR and Northern blotting. Liver RNA was reverse transcribed using a specific exon 8 primer, and the resulting CDNA was used for PCR amplification of a region spanning the exon 5 deletion, using primers located in exon 3 and exon 7 . Internal 20-mer probes derived from exons 3 and 5 were used to identify the resulting bands by Southern analysis (Fig. 2A). PCR using cDNA derived from PRLR ${ }^{+/+}$liver RNA and Southern analysis with the exon 3 probe revealed multiple specific bands. In gut, similar multiple bands have been shown previously to be transcripts of the receptor in which one or more exons are missing (Nagano et al. 1995). When cDNA derived from PRLR $^{-/-}$liver RNA was used, the same pattern of multiple bands was observed; however, 
A

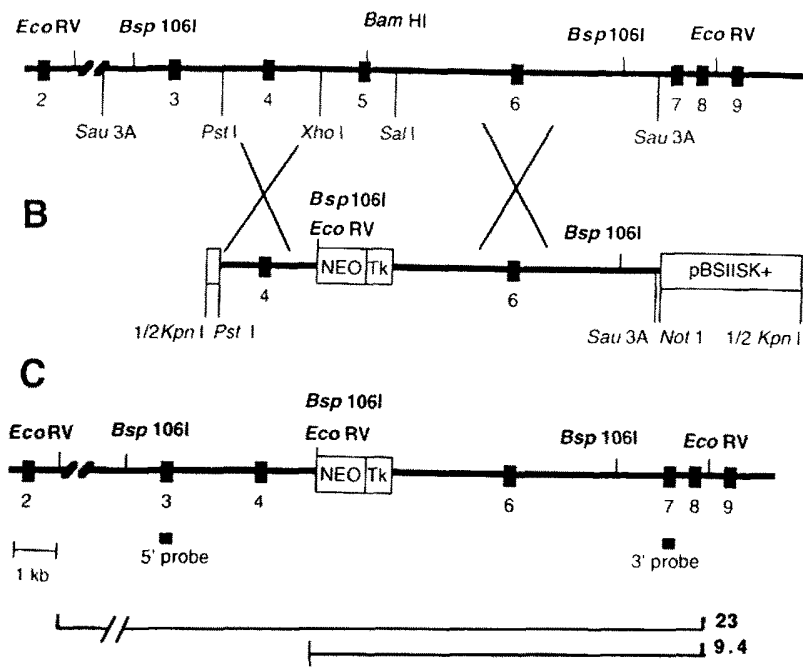

D

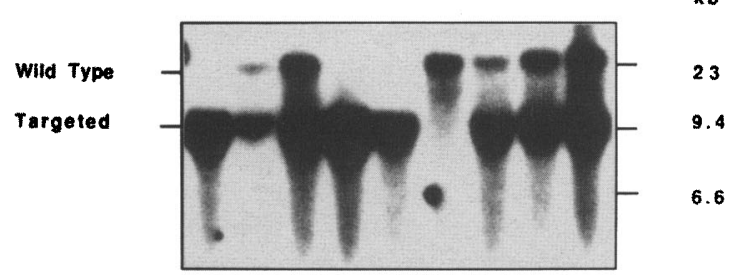

Figure 1. Targeted disruption of the PRLR gene. $(A)$ Portion of the PRLR gene indicating exon positions /numbered black boxes; size not to scale) and location of restriction enzyme sites used for vector construction (regular type, lower position) and Southern analysis (boldface, upper position). A gap of $6 \mathrm{~kb}$ that occurred in the $\lambda$ clones is indicated. $(B)$ Structure of the targeting vector constructed in plasmid Bluescript II ( $\mathrm{SK}+)$ and linearized using KpnI. A portion of the PRLR gene containing exon 5 was replaced with the neomycin resistance gene driven by the thymidine kinase promoter (NEO-Tk), introducing Bsp106I and $E c o R V$ restriction enzyme sites as detailed in the Materials and Methods section. $(C)$ Structure of the recombined allele showing restriction enzyme sites and the position of DNA probes used for Southern analysis. (D) Southern analysis of tail DNA from a litter from $F_{1}$ heterozygous parents digested with EcoRV and probed with the 3 ' probe (exon 7 in its entirety). The wildtype allele $\{+\mid$ is seen as a $23-\mathrm{kb}$ band, whereas the mutant allele $(-)$ is seen as a $9.4-\mathrm{kb}$ band. PRLR ${ }^{+/+}$animals showed just the 23-kb band, heterozygotes (PRLR ${ }^{+/-}$) showed both the $23-\mathrm{kb}$ and 9.4-kb bands, and PRLR ${ }^{-1-}$ animals showed just the $9.4-\mathrm{kb}^{\mathrm{al}}$ lele.

all were decreased in size corresponding to the 170-bp deletion of exon 5 (Fig. 2A, top). This was shown by rehybridization with an exon 5 probe, which failed to detect any of the PCR products generated from PRLR $^{-1-}$ animals despite overexposure of the signal detected from $\mathrm{PRLR}^{+/+}$animals, confirming the deletion of exon 5 in PRLR $^{1-}$ animals (Fig. 2A, bottom). No signal was detected when the NEO cassette was used as a probe, indicating that potential cryptic splice sites in the NEO gene were not operating (data not shown). Northern blot analysis was also used to examine PRLR gene expression in these animals (Fig. 2B). Using the exon 5 probe, a single major mRNA transcript of $2.8 \mathrm{~kb}$ was observed in PRLR $^{+/+}$but not PRLR ${ }^{-/-}$animals, demonstrating that no PRLR mRNA containing exon 5 is transcribed.

\section{PRLR protein in $P R L R^{-/-}$mice}

The PRLR protein in PRLR ${ }^{-1-}$ mice was examined by Western blot and ligand-binding analysis.

The PRLR protein was immunoprecipitated from solubilized liver microsomes (to maximize sensitivity), and analyzed by immunoblot. The U5 antibody (Okamura et al. 1989) used recognizes an extracellular epitope located after the stop codon introduced by the exon 5 deletion. A strong signal for the PRLR was detected in the liver of $\mathrm{PRLR}^{+/+}$mice; however, no prolactin receptor protein could be detected in the liver of PRLR ${ }^{-1-}$ animals with the assay used (Fig. $2 \mathrm{C}$ ). Specific binding of ${ }^{125} \mathrm{I}$ recom-
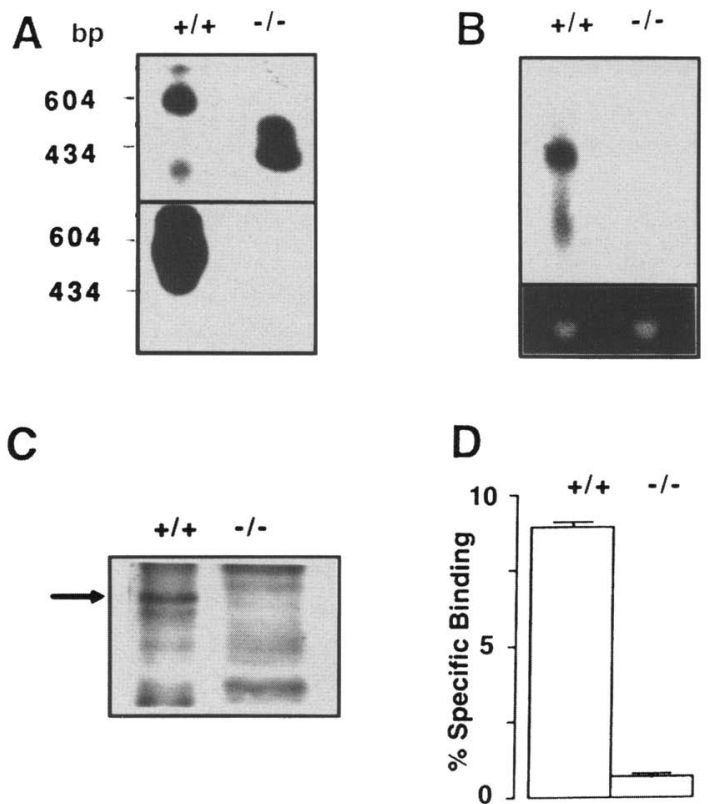

Figure 2. Analysis of PRLR mRNA, protein, and binding in PRLR $^{-1-}$ mice. (A) RNA isolated from female $\mathrm{PRLR}^{+/+}$and $\mathrm{PRLR}^{-1-}$ liver was reverse transcribed and a PRLR fragment spanning exons 3-7 was amplified by PCR. The PCR products were Southern blotted and hybridized sequentially with internal ${ }^{32} \mathrm{P}$-labeled oligonucleotide probes from exons 3 (top) and 5 (bottom). (B) RNA was also analyzed by a Northern blot hybridized with a cDNA probe complementary to exon 5 (top). Loading of RNA was controlled by staining of the gel with ethidium bromide (bottom). (C) Western blot analysis of protein immunoprecipitated from solubilized female PRLR ${ }^{+/+}$or PRLR $^{-1-}$ liver microsomes using the U5 anti-PRLR antibody and the enhanced chemiluminescence (ECL) detection system. The arrow indicates the position of the $\sim 40-\mathrm{kD}$ band representing the expected size of the PRLR. (D) Displacement of recombinant ${ }^{125} \mathrm{I}$ hGH binding by pituitary-derived oPRL $(2 \mu \mathrm{g} /$ tube $)$ from microsomes prepared from female PRLR ${ }^{+/+}$and PRLR ${ }^{-1-}$ livers. Bars represent the standard error of the mean for binding from livers of six females in each group. 
binant human growth hormone (hGH) to $\mathrm{PRLR}^{+/+}$and PRLR $^{-1-}$ liver microsomes was determined using competition with pituitary-derived ovine prolactin (OPRL). $\mathrm{PRLR}^{+/+}$animals showed an average of $9 \%$ specific binding (cpm of ${ }^{125} \mathrm{I}$-labeled hGH displaced by $2 \mu \mathrm{g} / \mathrm{ml}$ oPRL, expressed as a percentage of total $\mathrm{cpm}$ added), whereas livers of PRLR $^{-/-}$mice showed no significant specific binding of PRL. Similar results were obtained using iodinated oPRL. The $<1 \%$ apparent specific binding of PRL is attributable to low affinity displacement of the tracer from the growth hormone receptor, also present in liver. This receptor was used to control the quality of the microsome preparations, by the displacement of iodinated bovine growth hormone with bovine growth hormone. The RT-PCR, Northern analysis, Western blots, and binding data all indicate that the exon 5 deletion caused the complete absence of functional prolactin receptor in PRLR $^{-1-}$ animals.

Impaired mammary gland development and lactation in heterozygous females

When 6- to 8-week-old PRLR heterozygote $\left(\mathrm{PRLR}^{+/-}\right) \mathrm{F}_{1}$ females were mated with either $+/+$ or $+/$ - males, most of their first litter died within $24 \mathrm{hr}$, and virtually the entire litter had perished by $48 \mathrm{hr}$. All pups were observed to attach to the nipple and suckle; however, dead pups were dehydrated, with loose skin and loss of weight, and examination of their stomach contents showed air bubbles but no milk present, indicating that $\mathrm{PRLR}^{+/-}$females were unable to lactate. Only two of nine $F_{1}$ PRLR $^{+/-}$mothers kept some of their pups alive, to produce an overall pup survival rate of $14 \%$ of the 82 pups born (Table 1). When the $\mathrm{PRLR}^{+/-}$sisters of these animals had their first litter at 20 weeks of age, all produced surviving pups, and the overall survival rate was $76 \%$. When assessed by pup survival, this phenotype was not apparent after the second pregnancy, where all $F_{1}$ $\mathrm{PRLR}^{+/-}$females produced surviving pups at an overall $96 \%$ survival rate.

A similar phenotype was also seen at the first lactation in heterozygous $F_{2}$ females. In the test group of $21 \mathrm{~F}_{2}$ PRLR $^{+/}$, 9 mothers $(43 \%)$ were able to produce some surviving young (compared to $22 \%$ for the $F_{1}$ mothers), and overall $24 \%$ of pups survived when nursed by $F_{2}$ $\mathrm{PRLR}^{+/-}$mothers, compared to $14 \%$ from $\mathrm{F}_{1}$ mothers.
The same lactational phenotype was observed for both E8 and $\mathrm{H} 2$ strains on two different genetic backgrounds (C57BL/6 $\times 129$ and $129 \mathrm{~F}_{1}$ ).

Histological examination of the mammary glands from the $F_{1}$ animals after $48 \mathrm{hr}$ of their first lactation showed that lactational performance was correlated with the degree of mammary gland development. Mammary glands from nonlactating mothers showed very little development, whereas those from mothers with some surviving pups showed modest development when compared to the highly developed state of the mammary glands from PRLR ${ }^{+/+}$mothers (Fig. 3).

Combined, these results demonstrate that two functional alleles of the PRLR are required for correct lactation and that this phenotype in heterozygotes is attributable primarily to a deficit in the degree of mammary gland development.

\section{Heterozygote maternal behavior}

Some, but not all PRLR ${ }^{+/-}$mothers of 6-8 weeks and 20 weeks of age were observed to scatter their pups throughout the cage, often burying them completely in sawdust. The pups were left unattended in this state for hours and became cold and sometimes died. When the mother reformed the nest, a pup was often left outside and not retrieved, whereas the others were suckled. This behavior was never observed among $\mathrm{PRLR}^{+/+}$and multiparous $\mathrm{PRLR}^{+/}$females. In addition, $\mathrm{PRLR}^{+/-}$females generally did not eat their dead pups, in contrast to $\mathrm{PRLR}^{+/+}$females.

\section{Homozygous females are sterile}

$\mathrm{PRLR}^{-/-}$females when mated either with $\mathrm{PRLR}^{-/-}$or $\mathrm{PRLR}^{+/+}$males were infertile. Even after a 2-month period, pregnancy was never observed. The presence of vaginal seminal plugs was checked daily in a series of 11 $\mathrm{PRLR}^{-1-}$ females housed with PRLR ${ }^{+/+}$males of established fertility (Fig. 4); approximately half of the PRLR ${ }^{-/-}$ females mated every 4 days, whereas one animal mated every 3 days and the other PRLR $^{-/-}$females mated irregularly, every 3 to 4 days. In contrast, $\mathrm{PRLR}^{+/+}$females mated only every 12 days with vasectomized males. These results are indicative of the presence of a number of reproductive deficiencies in PRLR ${ }^{-1-}$ females. First, all

Table 1. Mothers with survivors and pup survival at first and second lactation from $F_{1}$ and $F_{2}$ mothers

\begin{tabular}{|c|c|c|c|c|}
\hline \multirow[b]{2}{*}{ Generation } & \multicolumn{2}{|c|}{ First lactation } & \multicolumn{2}{|c|}{ Second lactation } \\
\hline & $\begin{array}{l}\text { mothers with } \\
\text { survivors }^{\mathrm{a}}\end{array}$ & pup survival $^{\mathrm{b}}$ & $\begin{array}{l}\text { mothers with } \\
\text { survivors }\end{array}$ & pup survival $^{\mathrm{b}}$ \\
\hline $8 w(+1-)$ & $2 / 9 \quad(22 \%)$ & $11 / 82(14 \%)$ & $8 / 8(100 \%)$ & $75 / 79(96 \%)$ \\
\hline $20 \mathrm{w}(+/-)$ & $6 / 6(100 \%)$ & $57 / 75(76 \%)$ & $3 / 3(100 \%)$ & $34 / 38(90 \%)$ \\
\hline $8 w(+1-1$ & $9 / 21(43 \%)$ & $41 / 169(24 \%)$ & $8 / 9(89 \%)$ & $41 / 70(59 \%)$ \\
\hline
\end{tabular}

${ }^{a}$ Number of survivors over the total number of mothers.

${ }^{b}$ Number of surviving pups out of total. Percentages are indicated in parentheses. 
A
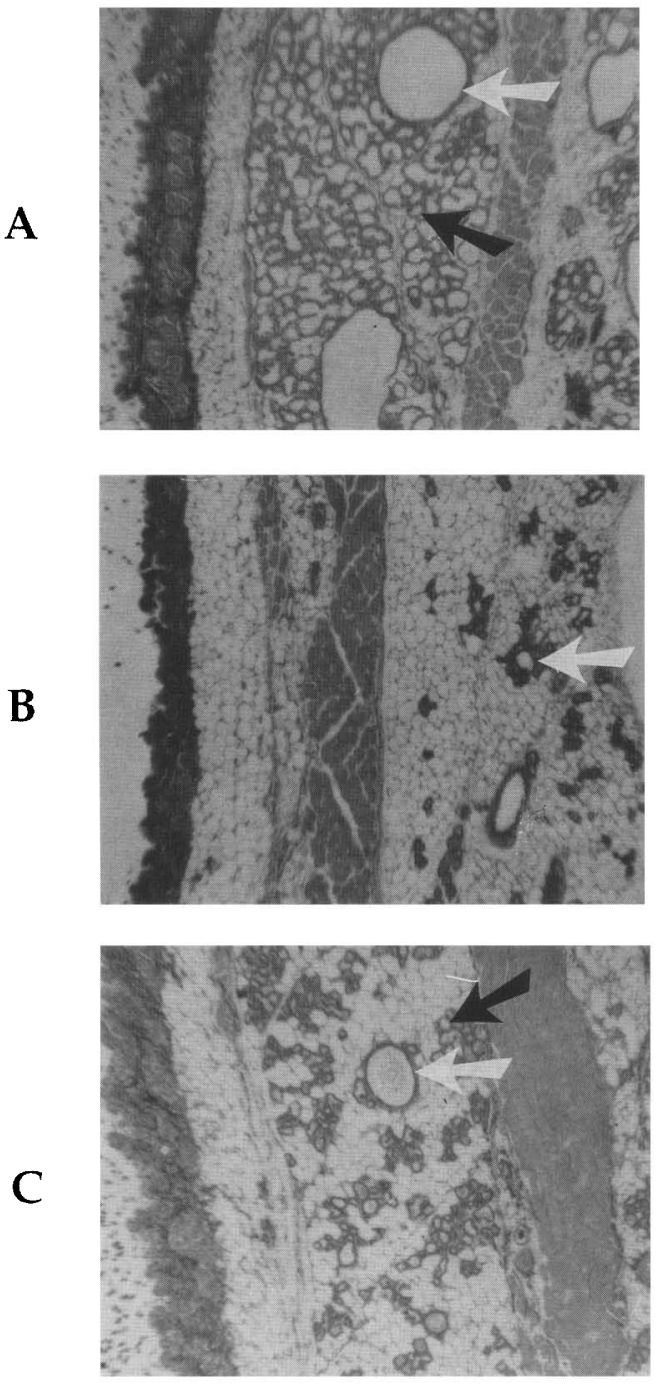

Figure 3. Histology of second thoracic mammary glands from $\mathrm{F}_{1} \mathrm{PRLR}^{+/+}$and $\mathrm{PRLR}^{+/-}$females exhibiting varying first lactational abilities. (A) $\mathrm{PRLR}^{+/+}$mother $48 \mathrm{hr}$ postpartum. $(B)$ $\mathrm{PRLR}^{+/-}$mother unable to lactate $48 \mathrm{hr}$ postpartum. (C) $\mathrm{PRLR}^{+/-}$mother showing partial lactation at $48 \mathrm{hr}$ postpartum (Original magnification, $100 \times$ ). For each panel, the tissue is oriented with the skin at the left, followed to the right by adipose tissue, mammary epithelial cells and alveoli, muscle, and more mammary tissue in $A$; in $B$, there is a complete absence of mammary epithelial cells and alveoli, but ducts are abundant; in $C$, the same organization of the tissue as in $A$, except fewer alveoli. (White arrows) Ducts; (black arrows) alveoli.

$\mathrm{PRLR}^{-/-}$females were sterile despite regular mating. Second, mating did not produce a pseudopregnancy in PRLR $^{-1-}$ females, as it did in the $\mathrm{PRLR}^{+/+}$females for the 12 days after mating. This was confirmed by examination of estrogen levels (data not shown), which showed a large increase on day 3 after the vaginal plug as the animals again entered estrus. Third, the irregular mating patterns of half of the females indicates an alteration of estrous cyclicity.
To investigate the cause of sterility of the $\mathrm{PRLR}^{-/-}$ females, the preimplantation development of embryos in $\mathrm{PRLR}^{+/+}$and $\mathrm{PRLR}^{-/-}$females was compared after mating to $\mathrm{PRLR}^{+/+}$males of established fertility. The embryos were flushed from the oviduct at various times, and their development were determined (see Table 2). Multiple abnormalities were observed in the $\mathrm{PRLR}^{-1-}$ females; fewer eggs were fertilized, oocytes at the germinal vesicle stage were released from the ovary, and fragmented embryos were found. The number of eggs ovulated was reduced in the $\mathrm{PRLR}^{-1-}$ females as compared to controls, and this observation was supported by histological investigation showing fewer primary follicles in $\mathrm{PRLR}^{-1-}$ ovaries (data not shown). Most important, fertilized eggs develop poorly to the blastocyst stage in PRLR $^{-/-}$animals. Only $19 \%$ of blastocysts were recovered at day 3.5 in the uterus of $\mathrm{PRLR}^{-/}$versus $85 \%$ in wild-type animals. Interestingly, single cell fertilized eggs were recovered at all of the stages studied (see Table 2 ), suggesting for most oocytes that an arrest of development occurred immediately after fertilization. To test whether the absence of development of the fertilized eggs in the $\mathrm{PRLR}^{-/-}$females was attributable to the lack of receptor in the oocytes or to the oviduct environment, transplantation experiments were performed. $\mathrm{PRLR}^{+/+}$ and $\mathrm{PRLR}^{-1-}$ females were mated to $\mathrm{PRLR}^{+/+}$males and fertilized single or two-cell stage embryos were flushed from their oviducts and reimplanted into the oviducts of pseudopregnant $\mathrm{F}_{1} \mathrm{C} 57 \mathrm{BL} / 6 \times \mathrm{CBA}$ foster mothers at day 1 . Of the 25 embryos recovered from $\mathrm{PRLR}^{+/+}$females, 13 produced normal day 12 embryos, whereas of the 22 embryos recovered from $\mathrm{PRLR}^{-1-}$ females, 15 also produced normal embryos (Table 3). When this experiment was repeated using fertile PRLR $^{-1-}$ males (to exclude the possible paternal contribution of PRLR to the embryol a similar rate of normal embryos was recovered, demonstrating that the eggs are viable, and thus that the environment of the embryo in the oviduct is deficient. Moreover, when -/- embryos were recovered at day 19 and when fostered by $\mathrm{F}_{1} \mathrm{C} 57 \mathrm{BL} / 6 \times \mathrm{CBA}$ females, all reached adulthood.

Despite the fact that occasionally we found blastocysts in the uterus of PRLR ${ }^{-1-}$ females at day 3.5, pregnancy was never observed.To examine whether the uterus of PRLR ${ }^{-1-}$ females was able to accept the implantation of wild-type embryos, three $\mathrm{PRLR}^{+/+}$or $\mathrm{PRLR}^{-/-}$ females were mated with vasectomized males, and 2.5 days after a vaginal seminal plug was observed, seven to eight $+1+$ blastocysts were reimplanted into the same uterine horn. Although 15 of 21 blastocysts reimplanted into $\mathrm{PRLR}^{+/+}$females produced normal fetuses, none of 24 blastocysts were able to implant in PRLR $^{-1-}$ females (Table 4), indicating that the uterus of these animals is refractory to implantation.

Thus, the absence of PRLR in female mice results in reduced ovulation, reduced fertilization, and almost complete arrest of preimplantation development. The small number of embryos that progress to the blastocyst stage are released into an environment refractory to implantation. The outcome is complete sterility. 


\section{Ormandy et al.}

Figure 4. Seminal vaginal plug frequency in PRLR $^{-1-}$ and PRLR ${ }^{+/+}$animals. PRLR ${ }^{-1-}$ females mated individually to $\mathrm{PRLR}^{+/+}$males of established fertility were checked daily for seminal vaginal plugs, indicated by a filled box corresponding to the day on which the plug was found. Individual data representative of three vaginal plug patterns found is shown. (Top pattern) One female; (middle pattern) four females; (bottom pattern) six females. Individual data representative of the pattern obtained from the mating of six $\mathrm{PRLR}^{+/+} \mathrm{fe}$ males to sterile males are shown below.

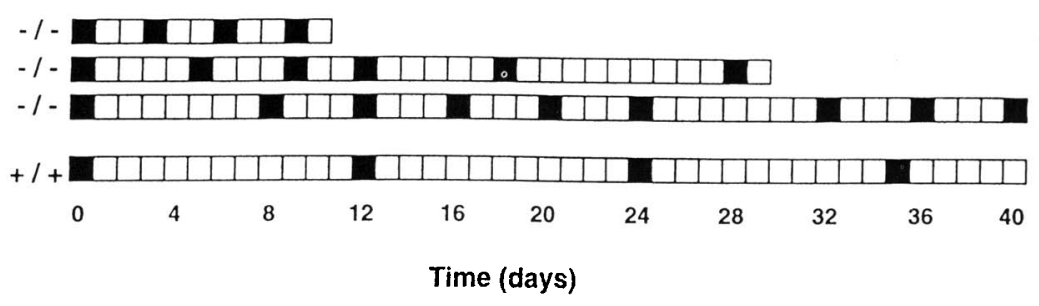

\section{Homozygous male fertility}

The fertility of a group of fifteen 12- to 18-week-old PRLR $^{-1-}$ males was examined by housing each separately for 50 days with a 12 - to 14 -week-old $\mathrm{PRLR}^{+/+}$ female of proven fertility. Vaginal plugs were checked daily. Seven males produced a pregnancy after detection of the first vaginal plug, and all these females became pregnant again immediately after delivery, for a total of three pregnancies. When these males were later each housed separately with four females, initial mating produced a pregnancy in all cases, even when two of the females were simultaneously in estrus. Therefore, these seven males were judged to be fully fertile. Five of the 15 males were, however, judged to be partially fertile, as multiple vaginal plugs were required for successful fertilization and pregnancy. Three of the 15 males $(20 \%)$ were completely infertile, and never produced a litter. Thus, 8 of $15 \mathrm{PRLR}^{-1-}$ males had fertility problems. These males showed normal sexual behavior when a foreign female not in estrus was added to their cage. At estrus, all females showed vaginal plugs, indicating normal mating, intromission, and ejaculation. Testes were of normal size and histological examination of testes from fertile, semifertile, and infertile animals showed no obvious differences or abnormalities, with clearly de- fined germinal cell layers and spermatocytes present in the seminiferous tubules. Accessory organs were all present and of normal size and with no obvious morphological or histological abnormalities. At this stage, the cause of male infertility is not known.

\section{Discussion}

Late fetal or neonatal lethality was the expected phenotype of PRLR ${ }^{-/-}$animals. As PRLR expression rises dramatically in a number of rodent tissues during the late stages of pregnancy, and prolactin and placental lactogens are detectable in fetal blood (Freemark et al. 1995), suggesting that lactogenic hormones begin to exert major effects during this period in preparation for the transfer to autonomous life. In contrast, $\mathrm{PRLR}^{-/-}$animals were born and survived until adulthood. A number of phenotypes were observed, however, in both heterozygous and homozygous animals.

\section{Mammary gland development and lactation}

The mammary gland undergoes development in utero, at puberty (mainly ductal development), and during pregnancy (ductal and alveolar development). The essential hormonal factors regulating the later two phases in mice

Table 2. Preimplantation development of eggs from $P R L R^{+/+}$and $P R L R^{-1-}$ animals from days $0.5-3.5$

\begin{tabular}{|c|c|c|c|c|c|c|}
\hline \multirow{2}{*}{$\begin{array}{l}T \\
\text { |days) }\end{array}$} & \multirow{2}{*}{$\begin{array}{l}\text { Female } \\
\text { genotype }\end{array}$} & \multirow{2}{*}{$\begin{array}{l}\text { Undeveloped } \\
\text { eggga }^{\mathrm{a}}\end{array}$} & \multicolumn{2}{|c|}{ Stage } & \multirow[b]{2}{*}{ Morula } & \multirow[b]{2}{*}{ Blastocyst } \\
\hline & & & one-cell & two-cell & & \\
\hline \multirow{2}{*}{0.5} & $+1+$ & $2(4 \%)$ & $44(96 \%)$ & 0 & 0 & 0 \\
\hline & $-1-$ & $15(42 \%)$ & $21(58 \%)$ & 0 & 0 & 0 \\
\hline \multirow{2}{*}{1.5} & $+1+$ & $4\{9 \%\}$ & 0 & $43(91 \%)$ & 0 & 0 \\
\hline & $-1-$ & $21(55 \%)$ & $8(21 \%)$ & $9(24 \%)$ & 0 & 0 \\
\hline \multirow{2}{*}{2.5} & $+1+$ & $3(10 \%)$ & 0 & 0 & $28(90 \%)$ & 0 \\
\hline & $-1-$ & $24(61 \%)$ & $10(25 \%)$ & 0 & $5(14 \%)$ & 0 \\
\hline \multirow{2}{*}{3.5} & $+1+$ & $4(15 \%)$ & 0 & 0 & 0 & $23(85 \%)$ \\
\hline & $-1-$ & $12(75 \%)$ & $1(6 \%)$ & 0 & 0 & $3(19 \%)$ \\
\hline
\end{tabular}

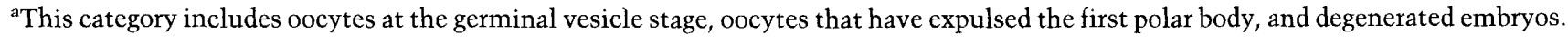


Table 3. Reimplantation of $P R L R^{-1-}$ embryos into wild-type females

\begin{tabular}{|c|c|c|c|}
\hline Genotype & $(n)$ & $\begin{array}{l}\text { Fertilized } \\
\text { embryos } \\
\text { recovered }\end{array}$ & Embryos \\
\hline$+1+$ & $(3)$ & 25 & 13 \\
\hline$+1-$ & (6) & 22 & 15 \\
\hline$-1-$ & $(6)$ & 30 & 17 \\
\hline
\end{tabular}

Fertilized one-cell and two-cell embryos were recovered from $\mathrm{PRLR}^{+/+}$or PRLR ${ }^{-1-}$ females mated with either wild-type males or fertile $\mathrm{PRLR}^{-/-}$males and reimplanted into pseudopregnant foster mothers. The number of implanted embryos was determined between days 12 and 19 .

have been established to be estrogen, adrenocorticoid, and growth hormone during puberty and estrogen, progesterone and prolactin during pregnancy (Nandi 1958; Neville and Daniel 1987). In the mouse, these hormones produce some development with each estrous cycle, and massive development at pregnancy that never fully regresses after estrus or weaning, resulting in ever-increasing alveolar and ductal development with each episode (Vonderhaar 1988). As prolactin has long been known to be essential for mammary gland development, lactational problems were expected in females carrying a null mutation of the PRLR gene. However, we were surprised when animals that carried only one mutated allele displayed such a phenotype. These observations suggest that the epithelial cell proliferation during pregnancy and the postpartum period depend on a threshold of PRLR expression that is unobtainable with just one functional gene, which is probably being transcribed at a maximal rate, given that the level of PRLR is closely controlled in mammary gland (Ormandy and Sutherland 1993). In heterozygous mice where the level of the receptor is reduced, mammary gland proliferation is insufficient to insure lactation at the first pregnancy but further estrous cycles or a single pregnancy lead to the development of a mammary gland capable of producing milk. Nursing is accomplished by heterozygous females by the second pregnancy or in older animals. Although no effect on the mammary glands of heterozygous animals have been reported for null mutations of the estrogen or progesterone receptor genes (Korach 1994; Lydon et al. 1995), the complete absence of the progesterone receptor in homozygous animals results in a gland lack. ing terminal end buds with some branched ducts (Lydon et al. 1995).

Initial histological investigation of the virgin gland of mature $\mathrm{PRLR}^{-1-}$ animals indicated no dramatic differences as a result of the null mutation of the PRLR, with ductal tissue clearly present (data not shown), confirming that the PRLR is not essential for this stage of development similar to what has been reported for the null mutation of the progesterone receptor (Lydon et al. 1995). The effect of this mutation on mammary development during pregnancy will be analyzed by transplantation of $\mathrm{PRLR}^{-1-}$ mammary epithelium to $\mathrm{PRLR}^{+/+}$ mammary fat pads cleared of endogenous epithelial cells before puberty.

\section{Oocyte maturation}

The high number of eggs still containing germinal vesicles that were ovulated in PRLR ${ }^{-1-}$ animals indicates that the PRLR is important for oocyte maturation. Most of these were found on days 2.5 and 3.5 after the vaginal plug, suggesting that they may have been ovulated at a later time than those released at estrus; therefore, prolactin may be involved in follicular atresia. A number of studies have examined the prolactin concentration of follicular fluid in maturing ova. Generally, a higher level of prolactin is seen in follicles containing mature oocytes capable of being fertilized (Laufer et al. 1984; Bohnet et al. 1985; Reinthaller et al. 1987a,b; Gonen and Casper 1989; Seibel et al. 1989; Oda et al. 1991; Yoshimura et al. 1991), although others find no relationship (Messinis and Templeton 1987) or suggest a negative effect (Irahara et al. 1991). Using immature eggs collected from mouse ovaries, prolactin was found to increase the rate of germinal vesicle breakdown and subsequent fertilization and correct development in vitro (Randall et al. 1990). The failure of a significant proportion of eggs to undergo germinal vesicle breakdown within maturing $\mathrm{PRLR}^{-1-}$ follicles demonstrates directly the important influence of prolactin and its receptor on oocyte maturation or atresia.

\section{Fertilization and preimplantation development}

Fertilization rates were reduced in $\mathrm{PRLR}^{-1-}$ females compared to $\mathrm{PRLR}^{+/+}$controls when mated to $\mathrm{PRLR}^{+/-}$ males. Similar results were found using $\mathrm{PRLR}^{-1-}$ or $\mathrm{PRLR}^{+/+}$males, indicating that this effect is a result of a maternal deficiency. This may involve incomplete oocyte maturation, or a defect in the oviduct such as a reduced sperm transport to the ampulla or loss of a factor that enhances fertilization.

Most of the fertilized eggs failed to develop correctly in PRLR $^{-1-}$ mothers, with $<20 \%$ reaching the blastocyst stage. Reimplantation experiments clearly showed that embryos that failed to develop in PRLR ${ }^{-1-}$ mothers were capable of normal development when transferred to

Table 4. Reimplantation of wild-type blastocysts into $P R L R^{+/+}$or $P R L R^{-1-}$ females

\begin{tabular}{ccc}
\hline Genotype & $\begin{array}{c}\text { Reimplanted } \\
\text { blastocysts }\end{array}$ & $\begin{array}{c}\text { Recovered } \\
\text { embryos }\end{array}$ \\
\hline$+/+(3)$ & 21 & 15 \\
$-\mid-(3)$ & 24 & 0 \\
\hline
\end{tabular}

Blastocysts were reimplanted into uteri of females mated 2.5 days previously with vasectomized males. Uteri were opened 10-12 days later to determine the number of implanted embryos. The number of females tested is indicated in parentheses after the genotype. 
$\mathrm{PRLR}^{+/+}$foster mothers, regardless of embryonic or paternal genotype. Divergent effects of PRL on the rate of implantation development of mouse embryos have been reported (Yoshida et al. 1987; Yohkaichiya et al. 1988; Randall et al. 1990). The present studies exclude the absolute requirement for an oocyte PRLR in pre- and postimplantation embryonic development supporting previous investigations (Fukuda et al. 1988; Dodds et al. 1990) and indicating that the defect must reside in the environment in which the embryo develops. A number of factors in the oviduct that influence preimplantation development may be affected by the PRLR mutation. Estrogen and progesterone can influence the rate of ovum transport and preimplantation development (Roblero and Garavagno 1979). Initial measurement of estrogen levels in the $\mathrm{PRLR}^{-1-}$ animals showed abnormally high concentrations at estrus with residual values at day 0.5 of pregnancy remaining above previously reported levels (McCormack and Greenwald 1974). We cannot exclude that these high levels could interfere with normal development of the eggs; however, levels at day 1.5 were normal suggesting that this may not be the cause of the problem in $\mathrm{PRLR}^{-1-}$ animals. The phenotype seen in mice carrying a null mutation of the progesterone receptor (PR) was very different from that seen in PRLR ${ }^{-1}$ mice; there was a complete block of ovulation. Ovaries in $\mathrm{PR}^{-1-}$ animals showed an unusually large number of preovulatory follicles and an absence of functional corpora lutea (Lydon et al. 1995), whereas PRLR $^{-1-}$ mice had ovaries capable of ovulation, albeit at reduced rates and with problems with atresia.

The failure of trophic support of the corpus luteum by prolactin would be expected to reduce progesterone levels on day 2.5 of pregnancy, when progesterone levels normally rise (McCormack and Greenwald 1974). Injection of antibodies against progesterone blocks mouse embryo development at the four-cell stage on day 2.5 (Rider et al. 1987), but the failure of preimplantation development in $\mathrm{PRLR}^{-/-}$females occurs earlier, between days 0.5 and 1.5 and at this time progesterone levels are normal in PRLR ${ }^{-1-}$ females. These results indicate that the PRLR must trigger a signal that occurs earlier than prolactin-induced trophic support of the corpus luteum. Candidates include ovum factor, now identified as platelet activating factor (PAF), released by the fertilized eggs $\left(\mathrm{O}^{\prime}\right.$ Neill 1985), and early pregnancy factor (EPF), a multifactorial activity comprised of PAF, thirodoxin (Orozco et al. 1994), chaperonin 10 (Cavanagh and Morton 1994), and other uncharacterized molecules produced by the platelets of the oviduct and ovary in response to embryonic PAF (Sueoka et al. 1988). EPF is present in serum 24 hr after ovulation and stimulates lymphocytes to produce a suppressor of the delayed-type hypersensitivity reaction, potentially protecting the ovum from the maternal immune system and promoting embryo cleavage, in addition to acting as a growth factor (Morton et al. 1992). Synthesis of EPF by isolated mouse oviducts and ovaries is stimulated by prolactin, and prolactin cooperates with PAF to stimulate ovarian EPF in vivo in response to fertilization, whereas passive immunization with antibodies against EPF produces almost identical effects as the PRLR mutation, with $54 \%$ of eggs not developing beyond the fertilized egg and two-cell stage (Cavanagh et al. 1982; Athanasas et al. 1989, 1991).

\section{Embryo implantation and pseudopregnancy}

Uterine preparation for embryo implantation is dependent on continued estrogen and progesterone secretion by the corpus luteum of the ovary, which is supported by the pituitary in rodents during the first half of pregnancy (Astwood and Greep 1938). Recently, prolactin has been shown to stimulate progesterone synthesis by dispersed ovarian cells from midpregnant mice (Galosy and Talamantes 19951, demonstrating that lactogenic hormones can stimulate directly ovarian progesterone secretion. Furthermore, a nidatory ovarian estrogen surge is required to allow embryo implantation $\left(\mathrm{O}^{\prime} \mathrm{Neill}\right.$ and Quinn 1981). Thus, PRLR ${ }^{-1-}$ females probably cannot support the implantation of blastocysts because the corpus luteum does not receive pituitary prolactin support, and progesterone- and estrogen-dependent signals for implantation cannot occur.

After mating in rodents, the pituitary is responsible for nocturnal and diurnal surges of prolactin that are initiated by mechanical stimulation of the cervix and continued through neural control by the medial preoptic area for the diurnal surge and an area outside this structure for the nocturnal surge for 10-12 days irrespective of fertilization or implantation (Jakubowski and Terkel 1986). These prolactin surges are thought to induce pseudopregnancy (Gunnet and Freeman 1983), and the observation that the $\mathrm{PRLR}^{-1-}$ females remated every 3 to 4 days demonstrates that the PRLR is essential for the establishment of pseudopregnancy.

\section{Male infertility}

Prolactin may regulate testosterone production by Leydig cells through modulation of the effects of luteinizing hormone and of the level of its receptor (Kelly et al. 1991). Prolactin has been proposed to be involved in sperm capacitation (Shah and Sheth 1979). In vitro it has been reported that a short period of incubation with prolactin enhances in vitro fertilization rates (Fukuda et al. 1989|, whereas longer periods reduce in vitro fertilization rates (Fukuda et al. 1988; Mori et al. 1988), although others have seen no effect (Dodds et al. 1990). In addition, prolactin can influence the function of the accessory reproductive glands (Bartke 1980; Costello and Franklin 1994). The fact that half of the PRLR ${ }^{-/-}$males are fully fertile for the tested period indicates that this role of prolactin is replaceable by other regulatory factors. In this context, the influence of genetic background cannot be excluded. Further studies will be required to elucidate the role of the PRLR in male fertility.

\section{Conclusions}

The generation of a $\mathrm{PRLR}^{-/-}$mouse has provided a means of studying the role of the PRL receptor system in 
mice. Short and long forms of PRL receptor exist in the mouse. It is probable that most of the phenotypes observed are related to the absence of the long form of the receptor, as this is the major form in all cells involved in the reproductive system. Almost every aspect of female reproduction is altered in these animals: mating frequency, oocyte maturation, ovulation rates, pseudopregnancy, fertilization rates, control of preimplantation development, uterine receptivity to embryo implantation, mammary gland development, lactation, maternal behavior, and with less dramatic effects in males, unambiguously demonstrating that the PRLR is a key regulator of reproduction. The ability of this new model to provide novel insights into the function of lactogenic hormones and their receptor illustrates the power of the knockout approach to discover unknown roles for wellinvestigated molecules.

\section{Materials and methods}

Gene cloning, targeting vector construction, and generation of chimeric mice

The genomic 129/Sv mouse liver library used was constructed in lambda DASHII phage using size selected 12- to 20-kb Sau3A fragments inserted at the BamHI site, resulting in the insert being flanked by NotI sites with internal $\mathrm{T} 3$ and $\mathrm{T} 7$ regions at either end. Of $10^{6}$ plaques screened using the PRLRS3 cDNA probe (Davis and Linzer 1989) we found 20 positive colonies that were purified. DNA was digested to completion with a panel of 25 restriction enzymes chosen to contain rare and frequent cutters and Southern blotted. The fragments containing the coding sequence were identified using sequential hybridization of a panel of ${ }^{32} \mathrm{P}$-labeled 20-mer oligonucleotides chosen from throughout the PRLR cDNA sequence. Detailed restriction enzyme site mapping for the same 25 enzymes was undertaken using partial digestion of NotI-digested phage DNA and sequential hybridization with T3 and T7 oligonucleotides. Sequencing was performed using the Sequenase kit (Perkin Elmer).

A $12.5-\mathrm{kb}$ phage clone that contained exons 3 through 6 was subcloned into the NotI site of pBluescriptII (SK+) (Stratagene), previously altered to remove the XhoI to SalI portion of the multicloning site. A 3-kb fragment that contained exon 3 was removed using PstI and the vector was religated. A $1.5-\mathrm{kb}$ XhoISall fragment was removed that contained exon 5 (identifiable by a BamHI site present in the cDNA) and replaced with the similarly sized Tk-neo, excised using Sall and XhoI from the pMC1-neo plasmid (Stratagene), which had been altered previously to introduce EcoRV and Bsp106I (ClaI) sites in the polylinker. A subclone in which the direction of transcription of the NEO gene was directed against that of the PRLR was selected for use as the targeting vector, resulting in the destruction of both the XhoI and SalI sites (Fig. 1B).

The targeting vector was purified by double banding on $\mathrm{CsCl}_{2}$ gradients, linearized with $\mathrm{KpnI}$, and transfected by electroporation (Cellject, Eurogentec $230 \mathrm{~V} 450 \mu \mathrm{F}$ ) into log growth phase E-14.1 mouse embryonic stem cells (Kühn et al. 1991). Cells were plated into five $10-\mathrm{cm}$ dishes containing a confluent monolayer of G418-resistant mitomycin C-treated mouse embryonic fibroblasts and allowed to recover overnight before a change to fresh media containing $180 \mu \mathrm{g} / \mathrm{ml}$ of G418. Medium was replaced once in the first 5 days and then daily until day 12 when G418-resistant colonies were picked. Colonies were incubated $\left(37^{\circ} \mathrm{C}, 10 \mathrm{~min}\right)$, then manually dispersed by 10 passages through a yellow tip using the multichannel pipette. Half the cells were transferred to a 96-well plate containing confluent mouse embryonic fibroblasts previously prepared from day 12 embryos and treated with mitomycin $\mathrm{C}$ before storage in liquid nitrogen. When colonies had formed, cells were dissociated and medium containing $10 \%$ fetal calf serum and $10 \% \mathrm{DMSO}$ (final) was added; plates were overlayed with sterile mineral oil, wrapped in parafilm, and frozen slowly to $-80^{\circ} \mathrm{C}$ in a polystyrene box. The other half of the trypsinized colonies were plated in gelatinized 96-well plates and grown to confluence. DNA was prepared and digested with EcoRV and analyzed by Southern blots hybridized with an exon 7 probe. Replicates of positive clones were revived from the $-80^{\circ} \mathrm{C}$ freezer, expanded, and samples were frozen.

Blastocysts flushed at day 3.5 from the uteri of 8 -week-old C57BL/ 6 females naturally mated to C57BL/ 6 males were injected with 15 embryonic stem cells each, before reimplantation. Eight blastocysts were introduced into one uterus of pseudopregnant $\mathrm{C} 57 \mathrm{BL} / 6 \times \mathrm{CBA}$ females mated 2.5 days previously with vasectomized $\mathrm{C} 57 \mathrm{BL} / 6 \times \mathrm{CBA}$ males. Chimeric animals obtained were mated to $\mathrm{C} 57 \mathrm{BL} / 6$ or $129 / \mathrm{Sv}$ partners, and $\mathrm{F}_{1}$ agouti offspring were genotyped using Southern analysis with EcoRV and the exon 7 probe, of DNA derived from tail clips by overnight digestion at $37^{\circ} \mathrm{C}$ with $0.5 \%$ SDS, 1 mM EDTA, 100 $\mathrm{mM} \mathrm{NaCl}$, and proteinase $\mathrm{K}$, before centrifugation and isopropanol precipitation of the supernatant DNA. Heterozygous animals were crossed to produce the $F_{2}$ generation, which was also genotyped by this method. Alternatively, animals were genotyped by PCR amplification of the NEO gene using primers (GCTATTCGGCTATGACTGGG) and (GAAGGCGATAGAAGGCGATG) and exon 5 (GAGAAAAACACCTATGAATGTC) and (GTAAGTCACATCCACATAAAGT) with $1.5 \mathrm{~mm} \mathrm{MgCl}_{2}$ concentration for 35 cycles of denaturation $\left(45 \mathrm{sec}, 94^{\circ} \mathrm{C}\right)$, annealing $\left(60 \mathrm{sec}, 60^{\circ} \mathrm{C}\right)$, and extension $\left(45 \mathrm{sec}, 72^{\circ} \mathrm{C}\right)$.

\section{Analysis of gene expression}

RNA was reverse transcribed for $1 \mathrm{hr}$ at $37^{\circ} \mathrm{C}$ using an exon 8 -specific oligonucleotide and PCR was used to amplify a 604bp fragment between exons 3 and 7 using primers (AGCCTCTGATCTATTGCCTGTA) and (GTTTGATGACCTGTGAAGTGGA). The PCR products were run on a $2 \%$ Tris-Borate buffer containing EDTA (TBE)-agarose gel and capillary transferred to Hybond $\mathrm{N}+$ (Amersham) nylon membranes for Southern analysis using exon 3 and 5 probes, derived by PCR and labeled using the Megaprime kit. For Northern analysis, $20 \mu \mathrm{g}$ of RNA samples were denatured at $55^{\circ} \mathrm{C}$ for $15 \mathrm{~min}$ in formaldehyde before electrophoresis in a $1 \%$ agarose gel containing $2.2 \mathrm{M}$ formaldehyde and capillary transferred to Hybond $\mathrm{N}+$ membranes. Southern and northern blots were hybridized in Church buffer [ $1 \%$ BSA, $1 \mathrm{mM}$ EDTA, 7\% SDS, $0.5 \mathrm{M}$ phosphate buffer (pH 7.2)] overnight at $60^{\circ} \mathrm{C}$ before washes at $60^{\circ} \mathrm{C}$ in $1.0 \%$ SDS, $0.1 \times$ SSC until the background fell below $1-2 \mathrm{cps}$, as monitored with a hand-held ${ }^{32} \mathrm{P}$ monitor.

\section{Analysis of protein}

Whole mouse livers were homogenized using 10 strokes at 500 rpm of an ice-cooled glass/Teflon potter homogenizer in $5 \mathrm{ml}$ of $25 \mathrm{~mm}$ Tris- $\mathrm{HCl}(\mathrm{pH} 7.4)$ and $0.3 \mathrm{M}$ sucrose buffer. Homogenates were centrifuged at $800 g_{\mathrm{av}}$ for $20 \mathrm{~min}$ and the supernatant was centrifuged at $100,000 g_{\text {av }}$ for $1 \mathrm{hr}$. The high speed pellet (microsomal fraction/ was resuspended using a hand-held potter homogenizer at $200 \mu \mathrm{g}$ of protein $/ 100 \mu \mathrm{l}$ in $25 \mathrm{~mm}$ Tris- $\mathrm{HCl} / \mathrm{pH}$ 7.4), $10 \mathrm{mM} \mathrm{MgCl}_{2}$ (TM), aliquoted and stored at $-80^{\circ} \mathrm{C}$. Binding assays in $5-\mathrm{ml}$ plastic tubes contained $200 \mu \mathrm{g}$ of protein, 60,000 $\mathrm{cpm}$ of hormone iodinated using the chloramine $\mathrm{T}$ method 
(Hunter and Greenwood 1962), in the absence and presence of noniodinated hormone (final concentration, $2 \mu \mathrm{g} /$ tube) in a final volume of $500 \mu \mathrm{l}$ of $25 \mathrm{~mm}$ Tris- $\mathrm{HCl}(\mathrm{pH} 7.4), 10 \mathrm{mM} \mathrm{MgCl}_{2}$, and $0.1 \%$ BSA (TMB). Assays were incubated overnight at room temperature followed by the addition of $2 \mathrm{ml}$ of ice cold TMB and centrifugation at $3500 g_{\text {av }}$ for $30 \mathrm{~min}$. Tubes were drained inverted for $30 \mathrm{~min}$ and their rims blotted dry before counting in a gamma counter. Hormones used were oPRL (NIAMDD-oPRL16), a kind gift of the National Hormone and Pituitary Program NID, Bethesda, MD, bGH la kind gift of Dr. W. Baumbach, American Cyanamid Co., Princeton, NJ), and recombinant hGH (a kind gift of Dr. A. Ythier, Ares-Serono, Geneva, Switzerland). The same microsomes were analyzed by immunoprecipitation and Western analysis. Microsomes were solubilized by the addition of $0.5 \%$ Triton X-100 at $4^{\circ} \mathrm{C}$ on a wheel stirrer for $1 \mathrm{hr}$. They were centrifuged and the supernatant $(9 \mathrm{mg}$ of proteins) was incubated with $4 \mu \mathrm{g}$ of monoclonal antibody U5 to the PRLR (Okamura et al. 1989) overnight before the addition of goat anti-mouse IgG antibodies immobilized on agarose beads. The beads were collected by centrifugation and washed three times in TM-Triton X-100 before denaturation by boiling $5 \mathrm{~min}$ in $3 \%$ SDS, $5 \%$-mercaptoethanol in $12 \mathrm{~mm}$ Tris- $\mathrm{HCl}(\mathrm{pH} 6.8)$. Samples were electrophorized and electrotransferred to enhanced chemiluminescence (ECL)-nitrocellulose membranes. Membranes were incubated with $2 \mu \mathrm{g} / \mathrm{ml}$ of U5 antibody in 50 $\mathrm{mm}$ Tris- $\mathrm{HCl}(\mathrm{pH} 7.5), 200 \mathrm{~mm} \mathrm{NaCl}, 0.05 \%$ Tween $20,1 \%$ BSA, $0.01 \%$ azide (AIB) for $2 \mathrm{hr}$ at room temperature with gentle rocking. Membranes were washed three times for 15 min each in $50 \mathrm{ml}$ of $50 \mathrm{~mm}$ Tris- $\mathrm{HCl}(\mathrm{pH} 7.5), 200 \mathrm{~mm} \mathrm{NaCl}, 0.05 \%$ Tween 20 (WB) and then incubated with goat anti-mouse IgG linked to peroxidase in AIB for $1 \mathrm{hr}$ and washed four times for 20 min each in $50 \mathrm{ml}$ of WB. Bands were visualised using X-ray film and the ECL chemiluminescence kit.

\section{Recovery and staging of preimplantation embryos}

Embryos were recovered from the oviduct or uterus as described in Hogan et al. (1994). They were classed as follows: oocytes with a germinal vesicle, fertilized eggs when the polar body or two pronuclei were observed in single cell embryos, or undeveloped embryos, including unfertilized and degenerated embryos.

\section{Transplantation of embryos}

Embryos were transplanted into the oviduct or uterus of $F_{1}$ C57BL $/ 6 \times$ CBA foster mothers at days 1 or 2.5 , respectively, of pseudopregnancy as described in Hogan et al. (1994).

\section{Histological evaluation}

Mammary glands from $\mathrm{PRLR}^{+/+}$and $\mathrm{PRLR}^{+/-}$mice were removed and fixed in $4 \%$ formalin. Paraffin sections $(5 \mu \mathrm{m})$ were stained with hematoxylin-eosin-safran.

\section{Acknowledgments}

We thank M. Murphy, J. DiSanto, and L. Ferradini for helpful advice during the course of this work, M.C. Postel-Vinay for the iodinated hGH and hormone solutions, J. Antreassian and her staff for the steroid hormone assays, V. Goffin for the Western blot, A. Bègue for the gift of $129 / \mathrm{Sv}$ genomic library, D. Linzer for the gift of mouse cDNA, K. Rajewsky for ES 14.1 cells, C. O'Neill for critical review of the manuscript, and B. Le Jan and F. Labaille for DNA sequencing and plasmid preparation. C.J.O. was a C.J. Martin fellow of the National Health and Medical Research Council of Australia and a boursier of the Association pour la Recherche sur le Cancer, France; A.C. was a fellow of the Association pour la Recherche sur le Cancer. This work was supported by INSERM, C.N.R.S. Institut Pasteur France, and the Association pour la Recherche sur le Cancer.

The publication costs of this article were defrayed in part by payment of page charges. This article must therefore be hereby marked "advertisement" in accordance with 18 USC section 1734 solely to indicate this fact.

\section{References}

Adams, J.B. 1985. Control of secretion and the function of C19delta 5-steroids of the human adrenal gland. Mol. Cell. Endocrinol. 41: 1-17.

Arden, K.C., J.-M. Boutin, J. Diiane, P.A. Kelly, and W.K. Cavanee. 1990. The receptors for prolactin and growth hormone colocalize to the same region of human chromosome 5. Cytogenet. Cell Genet. 53: 161-165.

Astwood, E. and R. Greep. 1938. A corpus luteum-stimulating substance in the rat placenta. Proc. Soc. Exp. Biol. Med. 38: 713-716.

Athanasas, P.S., K.A. Quinn, T.Y. Wong, B.E. Rolfe, A.C. Cavanagh, and H. Morton. 1989. Passive immunization of pregnant mice against early pregnancy factor causes loss of embryonic viability. J. Reprod. Fertil. 87: 495-502.

Athanasas, P.S., H. Morton, G.F. Dunglison, and P.L. Kaye. 1991. Antibodies to early pregnancy factor retard embryonic development in mice in vivo. I. Reprod. Fertil. 92: 443-451.

Bartke, A. 1980. Role of prolactin in reproduction in male mammals. Fed. Proc. 39: 2577-2581.

Bazan, I.P. 1989. A novel family of growth factor receptors: A common binding domain in the growth hormone, prolactin, erythropoietin and IL-6 receptors, and the p75 IL-2 receptor B chain. Biochem. Biophys. Res. Commun. 164: 788-795.

Biswas, R. and B.K. Vonderhaar. 1987. Role of serum in the prolactin responsiveness of MCF-7 human breast cancer cells in long-term tissue culture. Cancer Res. 47: 3509-3514.

Bohnet, H.G., V. Baukloh, P. Kemeter, and W. Feichtinger. 1985. Prolactin and sex steroid concentrations in follicular fluids after different ovarian stimulation methods in IVF patients. Annal. N.Y. Acad. Sci. 442: 227-235.

Boutin, J.M., C. Jolicoeur, H. Okamura, J. Gagnon, M. Edery, M. Shirota, D. Banville, I. Dusanter-Fourt, J. Diiane, and P. Kelly. 1988. Cloning and expression of the rat prolactin receptor, a member of the growth hormone/prolactin receptor gene family. Cell 53: 69-77.

Boutin, J.M., M. Edery, M. Shirota, C. Jolicoeur, L. Lesueur, S. Ali, D. Gould, J. Diiane, and P.A. Kelly. 1989. Identification of a cDNA encoding a long form of prolactin receptor in human hepatoma and breast cancer cells. Mol. Endocrinol. 3: $1455-1461$.

Bridges, R.S. 1994. The role of lactogenic hormones in maternal behavior in female rats. Acta Paediatrica Supp. 397: 33-39.

Buck, K., M. Vanek, B. Groner, and R.K. Ball. 1992. Multiple forms of prolactin receptor messenger ribonucleic acid are specifically expressed and regulated in murine tissues and the mammary cell line HC11. Endocrinology 130: 11081114.

Buckley, A.R., C. Putnam, and D.H. Russell. 1985. Prolactin is a tumor promoter in rat liver. Life Sci. 37: 2569-2575.

Cavanagh, A.C. and H. Morton. 1994. The purification of earlypregnancy factor to homogeneity from human platelets and identification as chaperonin 10. Eur. J. Biochem. 222: 551560.

Cavanagh, A.C., H. Morton, B.E. Rolfe, and A. Gidley-Baird. 
1982. Ovum factor: A first signal of pregnancy? Am. J. Reprod. Immunol. 2: 97-101.

Clarke, D.L. and D.I.H. Linzer. 1993. Changes in prolactin receptor expression during pregnancy in the mouse ovary. Endocrinology 133: 224-232.

Clarke, D.L., B.J. Arey, and D.I. Linzer. 1993. Prolactin receptor messenger ribonucleic acid expression in the ovary during the rat estrous cycle. Endocrinology 133: 2594-2603.

Clevenger, C.V., W.P. Chang, W. Ngo, T.L.M. Pasha, K.T. Montone, and J.E. Tomaszewski. 1995. Expression of prolactin and prolactin receptor in human breast carcinoma. Evidence for an autocrine/paracrine loop. Am. J. Pathol. 146: 695-705.

Costello, L.C. and R.B. Franklin. 1994. Effect of prolactin on the prostate. Prostate 24: 162--166.

Das, R. and B. Vonderhaar. 1995. Transduction of prolactin's (PRL) growth signal through both long and short forms of the PRL receptor. Mol. Endocrinol. 9: 1750-1759.

Davis, J.A. and D.H. Linzer. 1989. Expression of multiple forms of the prolactin receptor in mouse liver. Mol. Endocrinol. 3: 674-680.

Dodds, W.G., J. Fowler, A. Peykoff, K.F. Miller, C.I. Friedman, and M.H. Kim. 1990. The effect of prolactin on murine in vitro fertilization and embryo development. Am. J. Obstet. Gyneco1. 162: 1553-1559.

Forsyth, I.A. 1986. Variation among species in the endocrine control of mammary growth and function: The roles of prolactin, growth hormone and placental lactogen. J. Dairy Sci. 69: 886-903.

- 1991. The biology of the placental prolactin/growth hormone gene family. In Oxford reviews of reproductive biology (ed. S.R. Milligan) pp. 97-148. Oxford University Press, Oxford, UK.

Freemark, M., M. Nagano, M. Edery, and P.A. Kelly. 1995. Prolactin receptor gene expression in the fetal rat. J. Endocrinol. 144: 285-292.

Fukuda, A., Y. Noda, T. Mori, C. Mori, H. Hashimoto, and K. Hoshino. 1988. Effects of prolactin on gametes and zygotes during in vitro fertilization in mice. I. In Vitro Fert. Embryo Transf. 5: 25-30.

Fukuda, A., C. Mori, H. Hashimoto, Y. Noda, T. Mori, and K. Hoshino. 1989. Effects of prolactin during preincubation of mouse spermatozoa on fertilizing capacity in vitro. $I$. In Vitro Fert. Embryo Transf. 6: 92-97.

Gala, R.R. 1991. Prolactin and growth hormone in the regulation of the immune system. Proc. Soc. Exp. Biol. Med. 198: $513-527$.

Galosy, S. and F. Talamantes. 1995. Luteotropic actions of placental lactogens at midpregnancy in the mouse. Endocrinology 136: 3993-4003.

Ginsberg, E. and B.K. Vonderhaar. 1995. Prolactin synthesis and secretion by human breast cancer cells. Cancer Res. 55: 2591-2595.

Gonen, Y. and R.F. Casper. 1989. Does transient hyperprolactinemia during ovarian hyperstimulation interfere with conception or pregnancy outcome? Fertil. Steril. 51: 1007-1010.

Gouilleux, F., H. Wakao, M. Mundt, and B. Groner. 1994. Prolactin induces phosphorylation of Tyr694 of Stat5 (MGF), a prerequisite for DNA binding and induction of transcription. EMBO J. 13: 4361-4369.

Gunnet, J.W. and M.E. Freeman. 1983. The mating-induced release of prolactin: A unique neuroendocrine response. Endocrinol. Rev. 4: 44-61.

Hogan, B., R. Beddington, F. Costantini, and E. Lacy. 1994. Manipulating the mouse embryo. Cold Spring Harbor Laboratory Press, Cold Spring Harbor, NY.

Hunter, W. and F. Greenwood. 1962. Preparation of iodine-131- labeled human growth hormone of high specific activity. Nature 194: 495-497.

Irahara, M., K. Azuma, S. Yamano, and T. Aono. 1991. Effect of prolactin in serum and follicular fluid on fertilization and cleavage of human oocyte. Hormone Res. 1: 45-46.

Jakubowski, M. and J. Terkel. 1986. Female reproductive function and sexually dimorphic prolactin secretion in rats with lesions in the medial preoptic-anterior hypothalamic continuum. Neuroendocrinol. 43: 696-705.

Kelly, P.A., J. Diiane, M.C. Postel-Vinay, and M. Edery. 1991. The prolactin/growth hormone receptor family. Endocrinol. Rev. 12: 235-251.

Korach, K.S. 1994. Insights from the study of animals lacking functional estrogen receptor. Science 266: 1524-1527.

Kühn, R., K. Rajewsky, and W. Müller. 1991. Generation and analysis of interleukin-4 deficient mice. Science 254: 707710.

Laufer, N., R.W. Botero, A.H. DeCherney, F. Haseltine, M.L. Polan, and H.R. Behrman. 1984. Gonadotropin and prolactin levels in follicular fluid of human ova successfully fertilized in vitro. J. Clin. Endocrinol. Metab. 58: 430-434.

Lebrun, J.J., S. Ali, V. Goffin, A. Ullrich, and P.A. Kelly. 1995a. A single phosphotyrosine residue of the prolactin receptor is responsible for activation of gene transcription. Proc. Natl. Acad. Sci. 92: 4031-4035.

Lebrun, J.J., S. Ali, A. Ullrich, and P.A. Kelly. 1995b. Prolinerich sequence-mediated Jak2 association to the prolactin receptor is required but not sufficient for signal transduction. I. Biol. Chem. 270: 10664-10670.

Lee, D.W. and E. Markoff. 1986. Synthesis and release of glycosylated prolactin by human decidua in vitro. I. Clin. Endocrinol. Metab. 62: 990-994.

Liu, Y., T. Ganguly, J. Hyde, and M. Vore. 1995. Prolactin increases mRNA encoding $\mathrm{Na}^{+}-\mathrm{TC}$ cotransport polypeptide and hepatic $\mathrm{Na}-\mathrm{TC}$ cotransport. Gastrointest. Liver Physiol. 31: G11-G17.

Lydon, J.P., F.J. DeMayo, C.R. Funk, S.K. Mani, A.R. Hughes, C.A. Montgomery, G. Shyamala, O.M. Conneely, and B.W. O'Malley. 1995. Mice lacking progesterone receptor exhibit pleiotropic reproductive abnormalities. Genes \& Dev. 9: 2266-2278.

McCormack, J. and G. Greenwald. 1974. Progesterone and oestradiol-17 $\beta$ concentrations in the periferal plasma during pregnancy in the mouse. J. Endocrinol. 62: 101-107.

Messinis, I.E. and A.A. Templeton. 1987. Relationship between intrafollicular levels of prolactin and sex steroids and invitro fertilization of human oocytes. Hum. Reprod. 2: 607609.

Montgomery, D.W., J.A. LeFevre, E.D. Ulrich, C.R. Adamson, and C.F. Zukoski. 1990. Identification of prolactin-like proteins synthesized by normal murine lymphocytes. Endocrinology 127: 2601-2603.

Mori, C., H. Hashimoto, K. Hoshino, A. Fukuda, Y. Noda, and T. Mori. 1988. Influences of prolactin upon spermatogenesis and spermatozoa during in vitro fertilization in mice. $/$. In Vitro Fert. Embryo Transf. 5: 61-66.

Morton, H., A.C. Cavanagh, P.S. Athanasas, K.A. Quinn, and B.E. Rolfe. 1992. Early pregnancy factor has immunosuppressive and growth factor properties. Reprod. Fertil. Dev. 4: $411-422$.

Nagano, M. and P.A. Kelly. 1994. Tissue distribution and regulation of rat prolactin receptor gene expression. Quantitative analysis by polymerase chain reaction. I. Biol. Chem. 269: $13337-13345$.

Nagano, M., E. Chastre, A. Choquet, J. Bara, C. Gespach, and P.A. Kelly. 1995. Expression of prolactin and growth hor- 
mone receptor genes and their isoforms in the gastrointestinal tract. Am. I. Physiol. 268: G431-G432.

Nandi, S. 1958. Endocrine control of mammary gland development and function in the $\mathrm{C} 3 \mathrm{H} / \mathrm{He} \mathrm{Crg} 1$ mouse. I. Natl. Cancer Inst. 21: 1039-1063.

Neville, M.C. and C.W. Daniel, eds. 1987. The mammary gland. Development, regulation, and function. In Plenum Press, New York, NY.

Nicoll, C.S. 1980. Ontogeny and evolution of prolactin's functions. Fed. Proc. 39: 2563-2566.

Nicoll, C.S. and H.A. Bern. 1972. On the actions of prolactin among the vertebrates: Is there a common denominator? In Lactogenic hormones (ed. G. Wolstenholme and J. Knight) pp. 299-327. Churchill Livingstone, London, UK.

Nicoll, C., N. Hebert, and S. Russell. 1985. Lactogenic hormones stimulate the liver to secrete a factor that acts synergistically with prolactin to promote growth of the pigeon crop-sac mucosal epithelium in vivo. Endocrinol. 116: 14491453.

Oda, T., Y. Yoshimura, Y. Takehara, S. Kohriyama, Y. Sano, K. Tanabe, T. Kobayashi, Y. Nakamura, T. Ohno, and S. Nozawa. 1991. Effects of prolactin on fertilization and cleavage of human oocytes. Hormone Res. 1: 33-38.

Okamura, H., J. Zachwieja, S. Raguet, and P.A. Kelly. 1989. Characterization and application of monoclonal antibodies to the prolactin receptor. Endocrinology 124: 2499-2508.

O'Neill, C. 1985. Partial characterization of the embryo-derived platelet-activating factor in mice. J. Reprod. Fertil. 75: 375380.

O'Neill, C. and P. Quinn. 1981. Interaction of uterine flushings with mouse blastocysts in vitro as assessed by the incorporation of $\left({ }^{3} \mathrm{H}\right)$ uridine of the embryo-derived platelet-activating factor in mice. I. Reprod. Fertil. 62: 257-262.

Ormandy, C.J. and R.L. Sutherland. 1993. Mechanisms of prolactin receptor regulation in mammary gland. Mol. Cell. Endocrinol. 91: $\mathrm{C} 1-\mathrm{C} 6$.

Orozco, C., I.Q. Clark, I.E. Cock, and F.M. Clarke. 1994. A description of the basic system of components in pregnant mice sera responsible for "early pregnancy factor" activity. $I$. Reprod. Fertil. 100: 291-297.

Parker, L. and W. Odell. 1980. Control of adrenal androgen secretion. Endocrinol. Rev. 1: 392-410.

Pellegrini, I., J.J. Lebrun, S. Ali, and P.A. Kelly. 1992. Expression of prolactin and its receptor in human lymphoid cells. MoI. Endocrinol. 6: 1023-1031.

Randall, G., S. Awadalla, and C. Shivers. 1990. Isolation, in vitro maturation, and fertilization of germinal vesicle oocytes obtained from the intact murine ovary. I. In Vitro Fert. Embryo Transf. 7: 314-320.

Reinthaller, A., J. Deutinger, C. Bieglmayer, P. Riss, T.E. Muller, F. Fischl, and H. Janisch. 1987a. Hormonal parameters in follicular fluid and the fertilization rate of in vitro cultured oocytes. Arch. Gynecol. 240: 207-210.

Reinthaller, A., J. Deutinger, P. Riss, T.E. Muller, F. Fischl, C. Bieglmayer, and H. Janisch. 1987b. Relationship between the steroid and prolactin concentration in follicular fluid and the maturation and fertilization of human oocytes. I. In Vitro Fert. Embryo Transf. 4: 228-231.

Rider, V., H. Moscoso, and M. Riffo. 1987. Anti-progesterone monoclonal antibodies affect early cleavage and implantation in the mouse by mechanisms that are influenced by genotype. J. Reprod. Fertil. 79: 33-43.

Roblero, L. and A. Garavagno. 1979. Effect of oestradiol-17 $\beta$ and progesterone on oviductal transport and early development of mouse embryos. J. Reprod. Fertil. 57:91-95.

Royster, M., P. Driscoll, P.A. Kelly, and M. Freemark. 1995. The prolactin receptor in the fetal rat: Cellular localization of messenger ribonucleic acid, immunoreactive protein, and ligand-binding activity and induction of expression in late gestation. Endocrinology 136: 3892-3900.

Rozakis-Adcock, M. and P.A. Kelly. 1991. Mutational analysis of the ligand-binding domain of the prolactin receptor. $I$. Biol. Chem. 266: 16472-16477.

Seibel, M.M., D. Smith, A.M. Dlugi, and L. Levesque. 1989. Periovulatory follicular fluid hormone levels in spontaneous human cycles. J. Clin. Endocrinol. Metab. 68: 1073-1077.

Shah, G.V. and A.R. Sheth. 1979. Is prolactin involved in sperm capacitation? Med. Hypoth. 5: 909-914.

Shirota, M., D. Banville, S. Ali, C. Jolicoeur, J.-M. Boutin, M. Edery, J. Diiane, and P.A. Kelly. 1990. Expression of two forms of prolactin receptor in rat ovary and liver. Mol. Endocrinol. 4: 1136-1142.

Sueoka, K., A.M. Dharmarajan, T. Miyazaki, S.J. Atlas, and E.E. Wallach. 1988. Platelet activating factor-induced early pregnancy factor activity from the perfused rabbit ovary and oviduct. Am. I. Obstet. Gynecol. 159: 1580-1584.

Thomas, K. and M. Capecchi. 1987. Site-directed mutagenesis by gene targeting in mouse embryo-derived stem cells. Cell 51: 503-512.

Vonderhaar, B. 1988. Regulation of development of the normal mammary gland by hormones and growth factors. In Breast cancer: Cellular and molecular biology (ed. M. Lippman and R. Dickson) pp. 252-266. Kluwer Academic Publishers, Boston, MA.

Walker, S.E., S.H. Allen, R.W. Hoffman, and R.W. McMurray. 1995. Prolactin: A stimulator of disease activity in systemic lupus erythematosus. Lupus 4: 3-9.

Warren, D.M., A.M. Azzarolo, L. Becker, K. Bjerrum, R.L. Kaswan, and A.K. Mircheff. 1994. Effects of dihydrotestosterone and prolactin on lacrimal gland function. Adv. Exp. Med. Biol. 350: 99-104.

Yohkaichiya, T., T. Fukaya, H. Hoshiai, and A. Yajima. 1988. Improvement of mouse embryo development in vitro by prolactin. Tohoku J. Exp. Med. 155: 241-246.

Yoshida, K., J.M. Lin, H. Otsuka, M. Takashima, and Y. Okamura. 1987. The effect of prolactin on the early embryogen esis of mice in vitro. Sangyo Ika Daigaku Zasshi 9: 181-186.

Yoshimura, Y., Y. Nakamura, H. Yamada, M. Ando, Y. Ubukata, T. Oda, and M. Suzuki. 1991. Possible contribution of prolactin in the process of ovulation and oocyte maturation. Hormone Res. 1: 22-32. 


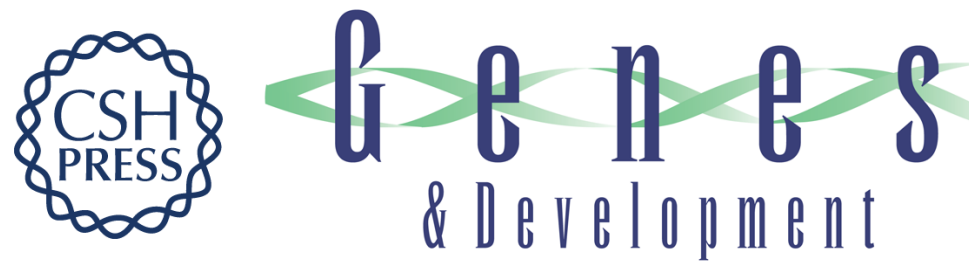

\section{Null mutation of the prolactin receptor gene produces multiple reproductive defects in the mouse.}

C J Ormandy, A Camus, J Barra, et al.

Genes Dev. 1997, 11:

Access the most recent version at doi:10.1101/gad.11.2.167

References This article cites 80 articles, 18 of which can be accessed free at: http://genesdev.cshlp.org/content/11/2/167.full.html\#ref-list-1

License

Email Alerting

Service

Receive free email alerts when new articles cite this article - sign up in the box at the top right corner of the article or click here.

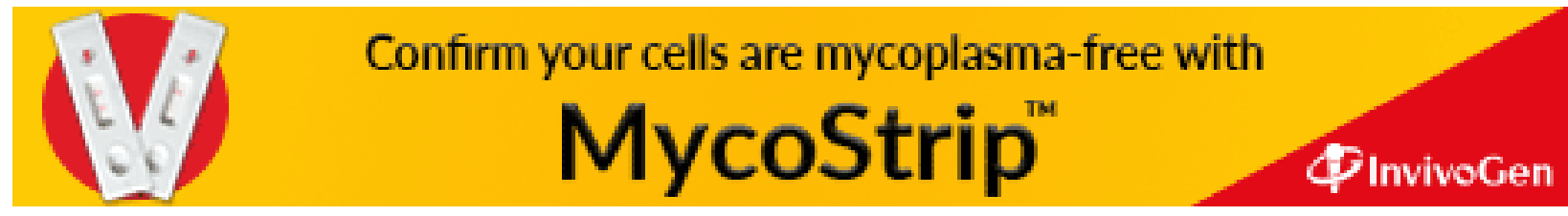

